\title{
Challenges of "School's Out, But Class's On" to School Education: Practical Exploration of Chinese Schools during the COVID-19 Pandemic
}

\author{
Xiaoqiao Cheng \\ Nanjing Normal University, Nanjing 210097, Jiangsu, China
}

\begin{abstract}
School's Out, But Class's On”, i.e. "suspending classes without stopping learning", specifically refers to China's education and teaching activities during the postponement period during the COVID19 pandemic prevention and control. This was an emergency measure to prevent and control the pandemic in the field of education in China, and it was also a continuation of school education in this special period. During the pandemic period, how school education should operate has become a topic of social concern. I herein discuss the origin and connotation of the concept of "School's Out, But Class's On", analyze the challenges of "School's Out, But Class's On" to school education, and then put forward measures for schools to respond to "School's Out, But Class's On" and explain the practical significance of "School's Out, But Class's On" for school education.
\end{abstract}

Sci Insigt Edu Front 2020; 5(2):501-516.

Doi: 10.15354/sief.20.ar043

Keywords: COVID-19 Pandemic; School's Out, But Class's On; School Education; Online Teaching; Students Study at Home

Correspondence to: Xiaoqiao Cheng, Professor, School of Institute of Education Science, Nanjing Normal University, Nanjing 210097, Jiangsu, China. Email: xqcheng2008@vip.163.com.

Conflict of Interests: None. 
A $\mathrm{T}$ the end of 2019, COVID-19 epidemic broke out in Wuhan of China. Because of the strong concealment and contagiousness, rapid spread, and extremely harmfulness, it quickly swept across other regions of the country. Subsequently, 30 provinces, municipalities, and autonomous regions nationwide successively initiated the first-level responses to a major public health emergency. In order to protect the lives and health of the people, the China government has organized a variety of forces to carry out prevention and control, and adopted various measures to prevent the epidemic from spreading on a large scale. According to a report published by the New York Times, about 760 million people in China were in a state of "confinement" (Robert, 2020).

In order to prevent the spread of the pandemic (Editor's note: due to the COVID-19 was defined as a pandemic by the World Health Organization, so we herein use "pandemic" over "epidemic".) to schools and reduce the impact of pandemic on teaching, the Chinese Ministry of Education has issued notices that required schools of all types to postpone the 2020 spring semester and encouraged the provision of guidance services for students' home study via the Internet. Thus, the implementation of "School's Out, But Class's On" during the postponed period could be realized.

Although "School's Out, But Class's On" was a measure for home study during the pandemic, its essence was still a continuation of school education. Schools are the main implementers of "School's Out, But Class's On". During the postponed period, each school integrated different types of resources to provide services and support for the home study and to ensure an effective implementation of "School's Out, But Class's On" policy. This article starts with a discussion of the school education, and then analyzes and summarizes the measures implemented by schools during the pandemic period, and hopes to provide reference for school education during the pandemic in other countries.

Because school education involves all types of schools including universities, middle schools and elementary schools, and due to the limitation of information, this article only analyzes the measures of elementary and middle schools during the pandemic period, and the situation of universities will be analyzed in another article.

\section{Origin, Connotation and Requirements of "School's Out, But Class's On"}

The concept of "School's Out, But Class's On" originated from a series of documents from the Chinese Ministry of Education. In order to control the deterioration of the pandemic, the State Council has repeatedly extended the Spring Festival holidays, and the postponement of the spring semester has become a foregone conclusion. On February 10th, 2020, the Ministry of Education issued the "Notice on Several Issues concerning Targeted Teacher Work during the Pandemic Prevention and Control". This notice proposed "suspending classes without stopping teaching and learning" from the perspective of teachers' work; it required education departments and schools to organize teachers to carry out online teaching according to local conditions, and to ensure that 
teachers undertake online teaching, tutoring, and homework corrections. All these work would be included in the workload as performance management, and thereby eliminated the worries of teachers (Ministry of Education of the People's Republic of China, 2020). On February 12th, 2020, the Ministry of Education and the Ministry of Industry and Information Technology jointly issued the "Notice on 'School's Out, But Class's On' Work Arrangements during the Postponed Period". This clarified that during the postponed period, in addition to the pandemic prevention and control, the major task was to conduct "School's Out, But Class's On" (Ministry of Education of the People's Republic of China, 2020). On February 28th, 2020, the Ministry of Education issued a "Notice on Coordinating the Prevention and Control of COVID-19 Pandemic in Education System and Education Reform and Development". This again emphasized "School's Out, But Class's On" from the perspective of online education and teaching, and believed that this was a test of the ability of the education system to respond to a major public health emergency. Therefore, it is of great significance to use information technology to promote education and teaching reform (Ministry of Education of the People's Republic of China, 2020). For this reason, "School's Out, But Class's On” has become a specific concept of education and teaching in elementary and middle schools during the pandemic prevention and control.

What is the deep meaning of "School's Out, But Class's On"? First of all, the understanding of its connotation is also constantly deepening and changing. "School's Out, But Class's On" refers to a state in which the school operates during the postponed start of the 2020 spring semester due to the pandemic. The appearance of this state has led to the inability of teachers and students to carry out educational and teaching activities in the school environment, and the school's operation can only be realized through the online platform. Therefore, "School's Out, But Class's On" does not only refer to online teaching or online learning, but a broad-based teaching and learning during a special period and in a special environment. The relevant notices issued by the Ministry of Education also gradually made it clearer that "School's Out, But Class's On" is a kind of broad-based learning, and online teaching is only one kind of format and it cannot completely replace classroom teaching (Ministry of Education of the People's Republic of China, 2020).

"School's Out, But Class's On", as the China government's overall deployment of school education during the pandemic prevention and control period, put forward the following seven requirements (Ministry of Education of the People's Republic of China, 2020):

(1) Strengthen student home study guidance. It is necessary to arrange the work and rest time reasonably, so that the teaching content and the teaching time are appropriate.

(2) Standardize online teaching behaviors, so as to prevent increasing the burden on teachers and students.

(3) Further improve the construction of online learning platforms for elementary and middle schools, and continuously enrich the learning resources, and pre- 
vent coping the normal classroom teaching methods, duration and arrangements.

(4) Strengthen the review mechanism of online teaching resources of elementary and middle school students, and strictly review the online learning resources to ensure a high quality.

(5) Make full use of the free learning resources provided by the national elementary and middle school network cloud platforms and the China Education Television Channel 4 air classroom to serve students' home study and ensure the learning needs of students in rural and remote areas.

(6) Integrate epidemic prevention, life education, public safety, and mental health into online e-learning.

(7) Concerned about the physical and mental health of students, guide students to strengthen physical exercise, and seriously improve myopia prevention and control.

\section{Challenges of "School's Out, But Class's On" to School Education}

A school is a place where the formal education activities can be provided. In the strict sense of formal education, school education excludes all informal learning opportunities. During the prevention and control of COVID-19 pandemic, the education and control measures of "School's Out, But Class's On" proposed by the Chinese government have expanded the scope of school education. It also includes so-called non-formal learning opportunities, thereby challenging school education in many ways. The "School's Out, But Class's On" initiative proposed by the China government has expanded the scope of formal school education. It also includes some so-called informal learning opportunities, which thereby challenges school education in many ways.

\section{Challenges to Traditional Forms of School Education}

In the traditional form of school education, schools and classrooms are the basic places for education and teaching. In the classroom, teachers pass knowledge to students, and students learn what teachers instructed, so this is obviously a typical form of education. In this form, teachers fulfill their responsibilities by completing the teaching tasks of each lesson, and students engage in learning and complete learning tasks under the teacher's supervision. The physical space of schools and classrooms has become a necessary condition for school education and teaching activities. However, during the postponed period, neither teachers nor students can come to school, and the physical space for regular education and teaching no longer exists. To complete the task of "School's Out, But Class's On", it is necessary to transfer the physical space of the traditional school education to the virtual space of the Internet platform. How teachers and students adapt to the virtual teaching space is a challenge to the traditional form of education. 


\section{Challenges to Teachers' Teaching Methods}

In traditional classroom teaching, teachers need to carry out teacher-student and student-student interaction in a variety of ways in order to attract students to participate in the classroom and reflect the teaching concept of "student as the main body". "School's Out, But Class's On" has brought about changes in the teaching environment, making teachers' teaching methods shift from offline classroom to online teaching. In comparison, online teaching cannot achieve the face-to-face emotional communication between teachers and students, and lacks real-time feedback of information and classroom constraints. When face-to-face classroom teaching is not available, and how to use online resources to implement online teaching activities based on the characteristics and rules of students' home study through online teaching is the second challenge that school education faces when implementing "School's Out, But Class's On”.

\section{Challenges to Student Learning Styles}

In the new round of China's basic education curriculum reform, promoting the development of students' innovative consciousness and practical ability through independent, cooperative, and inquiry learning methods has become one of the cores of curriculum reform. But all these are done under the guidance of the teacher's organization. During the pandemic, the family became the only place for students to learn, they left regular classroom teaching, and their autonomous learning became an essential learning method for students while performing "School's Out, But Class's On". Therefore, how to improve the self-study ability and interest of students in school education according to the characteristics of students' home study, and how to change the student's learning style under the premise of respecting the law of learning, and guide them to effectively learn at home is another challenge that the school education faces.

\section{Challenges to the Innovation of Teaching Resources}

Teaching resources are materials that can be used for the effective development of teaching. The quality of teaching resources has a pivotal impact on teaching results. In traditional classroom teaching, teaching resources mainly include materials such as textbooks, learning materials, courseware, and pictures, etc., whereas online teaching resources are rarely presented in school teaching. The implementation of "School's Out, But Class's On" has made online teaching the main teaching method. Correspondingly, the presentation and content of teaching resources also changed. First, the digitization of teaching resources is necessary, that is, transforming conventional teaching resources into digital resources as much as possible. The second is the diversification of teaching content. In addition to the curriculum content stipulated in the spring semester, pandemic prevention and control, home health education, mental health, and practical activities also need to be added into the instructing contents.

\section{Challenges to School Administration}


School administration is the activity of planning, organizing, coordinating, and controlling the school's education, teaching, scientific research, logistics, and staff and students. Through administration, the school combines various tasks and its constituent elements to give play to its overall function, thereby achieving its training goals for students and various work goals (Gu, 1988). To achieve the goal of administration, the school cannot do without effective communication and coordination between administers and teachers and students. During the postponed period, since all the school administrative personnel are at home, and how can school administers coordinate various types of staff to carry out their work, and handle the relationship between the school's unified regulations and the autonomous arrangements of teachers and students is a big challenge to school administration.

\section{School's Main Measures to Deal with "School's Out, But Class's On"}

While the Ministry of Education issued the "School's Out, But Class's On" notice, it also put forward seven requirements (Ministry of Education of the People's Republic of China, 2020). Each provincial and municipal education administration department had successively put forward the requirements of their own province and city in accordance with the actual situation. Schools at all levels following the provisions of the Ministry of Education and the provincial and municipal education administrative departments, and based on their actual situation, have formed their own initiatives. After several weeks of postponement, various measures of "School's Out, But Class's On" have been continuously improved. The main initiatives that have been implemented are summarized below.

\section{Improving Information Release, Publicity and Education}

With schools as the main body, use WeChat public account and other network channels to publish "Open Letters to All Teachers and Students of the School", "Open Letters to All Parents", etc., to carry out pandemic prevention knowledge publicity, announce the relevant postponed school policies, and promote the deployment of pandemic prevention and control work, publicize the school's online teaching work during the postponed period (The Education Department of Shandong Province, 2020).

Through the WeChat public account, publish the pandemic control information of the school and the area to the staff, students and parents, so that students and parents can learn more about the severity and seriousness of the pandemic. The school's "Pandemic Prevention and Control Guidebook" and "Pandemic Prevention and Control Brief News" were issued to guide teachers and students to master pandemic prevention and control knowledge and methods to develop good hygiene habits (Zibo Municipal People's Government, 2020).

Focusing on the moral education of pandemic prevention and control, publicize role models who were on the front lines of the pandemic prevention. In this way, a 
sense of overall situation and responsibility for preventing and controlling the pandemic was established. It helped students correctly judge and analyze various messages involving pandemic (The Education Department of Guangdong Province, 2020). Also, pandemic prevention works did by teachers and students were sent out every day.

\section{Formulate the Work Plan of "School's Out, But Class's On"}

According to the "Notice on Several Issues concerning Targeted Teacher Work during the Pandemic Prevention and Control" (Ministry of Education of the people's Republic of China, 2020), “Notice on 'School's Out, But Class's On' Work Arrangements during the Postponed Period" (Ministry of Education of the people's Republic of China, 2020), and "Notice on Coordinating the Prevention and Control of COVID-19 Pandemic in Education System and Education Reform and Development" (Ministry of Education of the people's Republic of China, 2020) issued by the Ministry of Education, all schools across the country have studied and worked out their own work plans. The content of the plan includes two major aspects, one is the work of pandemic prevention and control, and the other is the education and teaching work carried out using the Internet platform. These two aspects are essential to complement each other. Simply focusing on pandemic prevention and control without carrying out education and teaching has abandoned the school's basic responsibility; but only focusing on education and teaching without on pandemic prevention and control is a disregard for the physical and mental health of all teachers and students. So, a complete "School's Out, But Class's On" work plan must include both aspects of pandemic prevention and control and online education and teaching. Here are two typical cases that show the contents of the "School's Out, But Class's On" in their work plans via presenting both Tongshan University Road Experimental School in Xuzhou City, Jiangsu Province and Tangquan Middle School in Pukou District, Nanjing City in Jiangsu Province as examples.

On January 30, 2020, the University Road Experimental School in Tongshan District, Xuzhou City, Jiangsu Province issued a "Notice on Strengthening Pandemic Prevention and Control Measures" via WeChat public account (Xuzhou University Road Experimental School, 2020). They announced the school's pandemic prevention and control work plan to all staff, students and parents. The work plan includes the establishment of a pandemic prevention and control work leading group and a special working group; strictly implement closed campus management and cancel all collective activities; establish a registration and inspection schedule for all teachers and students to fully follow their movement; strengthen the timely reporting of information, and clarify the specific person to report pandemic defense and control information; all teachers, students and parents do not arrange activities such as gatherings, visiting relatives and friends, and perform self-isolation at home.

The work plan of Tangquan Middle School in Pukou District, Nanjing City, Jiangsu Province, divided "School's Out, But Class's On” into multiple stages (Dai \& Lin, 2020). Each stage has specific requirements for technical support, student learning, teacher instructing, learning schedules, teaching content, learning resources, and home- 
school co-education. The specific education and teaching requirements for studying subjects such as Chinese, mathematics, English, science, ethics and law, arts, as well as activities such as online theme learning, project-based learning, and housework were clearly defined in sections. Through the overall planning, guidance, inspection and evaluation, the implementation of the plan was guaranteed.

\section{Provide Technical Support for "School's Out, But Class's On"}

All school education and teaching work during "School's Out, But Class's On” requires network operation. Therefore, the Ministry of Education issued the "Notice on Supporting Education and Teaching Work with Informationization during the Pandemic Prevention and Control Period" on February 6th, 2020 (Ministry of Education of the People's Republic of China, 2020), to support the implementation of online teaching during the postponed period. The Ministry of Education organized the China Education and Research Network (CERNET) and telecommunications operation companies such as China Mobile, China Telecom, China Unicom, and China Satcom, etc. to strengthen the protection of national and local education public service platforms and various types of school networks. This provided fast and stable online services for schools in various regions to carry out online teaching, and help teachers, students and parents to obtain digital education resources. The Ministry of Education also required schools in all regions to rely on the national digital education public service system and various educational reform service platforms such to smooth the application of online learning spaces, and actively support school education and teaching activities including issuing notices, organizing online teaching, carrying out home-school coordination and tutoring students' learning.

\section{Select Appropriate Education Resources}

In order to support the implementation of "School's Out, But Class's On" in various schools, the Ministry of Education opened the national elementary and middle school network cloud platform (website: www.ykt.eduyun.cn). This teaching resource includes courses from the first grade of elementary school to the third grade of high school. Besides, a dedicated TV Channel-China Education TV Channel 4 was launched to cover the remote rural areas of the country with limited television signal. The Ministry of Education also organized some provincial-level education departments and elementary and middle schools to open online learning platforms to the country free of charge and provide electronic versions of relevant teaching materials for free. For example, the People's Education Publishing House has freely opened the digital teaching resource library of "People's Education Click Reading" to all (Ministry of Education of the People's Republic of China, 2020). Taking Henan Province as an example, the digital textbook service platform was free for all elementary and middle school students in the province. They launched a total of 154 digital textbooks that planed for 2020 spring semester and tens of thousands of supporting resources, which basically achieved full coverage of disciplines and semesters. The coverage rate was over $95 \%$. In addition to providing 
"digital teaching materials", the elementary and middle school digital teaching materials service platform also provided teachers and students with traditional cultural videos, book resources, and "one teacher for one excellent class" teaching case video resources (The Education Department of Henan Province, 2020).

Based on the rich education and teaching resources provided by the Ministry of Education and the provincial education department, school had studied and selected the most appropriate teaching platform and continuously optimized it to meet their technology and teaching foundation. Some schools divided resources into four types: live broadcasting resources, learning product resources, self-produced resources, and subject technology tools according to online teaching needs, to maximize the role of various resources in online teaching. For rural schools, the level of teachers and technology is limited, and the network of student families cannot fully realize platform online learning. Therefore, the school's online education is mainly carried out through mobile phones and the recorded online resources. Schools arranged online assignments and organized examinations to support "School's Out, But Class's On” to varying degrees.

As most schools in China have basically realized the requirements for the construction of education information infrastructure, and established a school education platform or resource library. This also enables these schools to rely on the existing teaching platform to strengthen the guidance of students' online learning resources when they launch "School's Out, But Class's On". At the same time, according to the characteristics of online learning and disciplines, we have carefully studied and provided curriculum resources suitable for students' online learning, and developed schoolbased teaching and learning resources such as digital protocol-guided learning that are suitable for students' learning (Xia, 2020).

\section{Strengthen the Guidance and Management of Teachers}

Facing the work of "School's Out, But Class's On", an important factor is the teaching ability of teachers. As early as the beginning of "School's Out, But Class's On" since it was launched on February 10th, 2020, the Ministry of Education requested in relevant documents that schools across the country should improve teachers' information technology capabilities and open and share teacher training resources. It also required each institution that undertakes national teacher training and provincial teacher training projects to organize online special training for teachers' long-distance teaching and information technology, and to provide free consultation and online guidance; at the same time, it required the provincial and municipal education departments to implement relevant supporting measures to strengthen the training of teachers' informatization ability to provide support and guarantee for teachers to carry out online education and teaching scientifically and efficiently (Ministry of Education of the People's Republic of China, 2020).

The teaching and research departments of the provinces across the country organized teams of teaching and researching staff to deeply study the rules and characteristics of online teaching, and actively explored both online and offline teaching modes 
and methods. They have carried out online collective lesson preparation, online listening and assessment, and other measures to serve the school's online teaching work, and urged schools to avoid online teaching by directly copying offline classroom teaching methods, duration and teaching arrangements (Shandong Provincial Institute of Education Sciences, 2020). The education departments of various provinces and cities have launched advanced teachers, subject leading teachers, and famous teachers to guide schools to formulate online teaching plans scientifically, record live broadcasting demonstration lessons, research and develop excellent curriculum resources, and guide teachers to focus on online course preparation and teaching (The Education Department of Shandong Province, 2020).

In order to make teachers' guidance and management accurately and precisely, after two weeks of online teaching in elementary and middle schools, the teaching department summed up the problems in online teaching in time, and focused the teachers on the needs of the online teaching matter. This includes:

(1) How to carry out online teaching to promote better home study for students?

(2) What should be the difference between the teaching schedule of online teaching and the regular school teaching?

(3) What kind of online teaching content is more suitable for students to learn?

(4) How to adopt a suitable form of online teaching?

(5) What aspects should be paid attention to in preparing for online teaching?

(6) What methods can promote teacher-student interaction?

(7) How can online teaching promote the improvement of students' autonomous learning ability?

(8) How to help the graduating class review for the exam?

(9) How to arrange and correct assignments, carry out Q \& A and feedback?

(10) How to develop school-based teaching and research for online teaching? (The Education Department of Zhejiang Province, 2020).

\section{Pay Attention to Students' Learning Status}

In order to adapt to the characteristics of students' home study, when the school organized and conducted online teaching, it paid close attention to the student's learning status and guided students to have better home study. During the home study, teachers' instructing time is reduced. Teachers stimulated students' motivation by giving students clear learning goals, and designed essential autonomous learning tasks based on the core content of teaching to increase students' participation in online learning. The school organized teachers to select high-quality learning resources to closely follow the teaching goals and content, meet the physical and mental characteristics of learners, promote effective but avoid inefficient learning. Instruct students to choose reasonable learning methods and use home learning opportunities brought by pandemic to cultivate students' good self-study habits and improve self-study quality and ability. We value students' practice, understand the teaching effect in time through practice, and then strengthen the learning effect and adjust their learning plans in a more focused manner. 
Stimulate learning through instant evaluation, strengthen successful experiences and self-confidence, and encourage them to participate in the learning process to meet the most basic learning requirements.

In the process of organizing online teaching, we need to always pay attention to motivate students' learning motivation and cultivate self-learning ability and level. Empirical research by Zhou et al. showed that students' learning motivation was highly correlated with autonomous learning and academic achievements (Zhou \& Li, 2020). In addition, we must focus on the students' experience on the network platform. Relevant research during the postponed period showed that the platform satisfaction used by online teaching had a high correlation with the overall satisfaction of students with online teaching, that is, the more satisfied students were with the online teaching platform, the more satisfied they were with the overall online teaching (Zhejiang Research Institute of Education Science, 2020).

During the "School's Out, But Class's On", schools must ensure that students from families with limited resources can participate in online teaching. It is necessary to carry out comprehensive investigations, find out the bases of students in difficult families, and understand the actual difficulties of students, including any necessary hardware such as smart phones and computers? Does his family have access to the network? Are they familiar with the use of smart devices? The school has extensively mobilized social forces to solve students' difficulties so that they can smoothly participate in online teaching activities.

\section{Close Communication between School and Parents}

During the postponed period, the family became the only place for students to study at home. Strengthening communication and cooperation between schools and families is an important measure to promote "School's Out, But Class's On".

In order to better manage students' home study, schools organized homeroom teachers to establish corresponding class platforms for communication management. Establish contact with students' families through multiple channels such as class QQ group, WeChat group or school platform, and school official WeChat. Build up a good, positive, smooth, and effective communication channel between the school and the family to maximize parental support and cooperation. Through the communication platform and collect the data of online viewing and homework submission to better understand their self study situation.

The school developed guidance for parents, and guided parents and students to make home study and living plans together, so that each student's home study and living plan could be formulated according to their home study characteristics and family circumstances, and realized "one student for one case". During the postponed period, students were living at home and their parents spent more time with their children together. Schools should help parents establish a sense of family education, help them create a good family learning environment, and ensure that students' home study pro- 
grams were put in place through the guidance and supervision of both schools and families.

It is necessary to establish a school notification system to parents. The school held an online parental conference once a week, during which the school informed parents of the home study situation, including statistics of home study time, the use of elearning tools, parental accompaniment, student learning status at each period, and homework completion. At the same time, school informed parents of the online teaching situation of teachers, including the preparation of lessons and teaching seminars. Put forward requirements for students' home study, ask parents to urge students to make a weekly study plan, arrange daily learning activities, and cultivate good study habits. Told them the expectations for parents, and hoped that parents could serve as role models, guide and supervise students "School's Out, But Class's On", and go along with their children through every day of the postponed spring semester.

\section{Pay Attention to the Physical and Mental Health of Students during Home Study}

When the Ministry of Education began to deploy "School's Out, But Class's On", it already paid attention to the physical and mental health of students during the pandemic prevention and control. It required elementary and middle schools to take care of the physical and mental health of students in the process of conducting online teaching and to control the appropriate amount of teaching content and the appropriate teaching time (Ministry of Education of the People's Republic of China, 2020).

In order to guide the school to promote the overall development of physical and mental health during students' home study, the Jiangsu Provincial Department of Education specially issued documents to schools to put forward specific suggestions on promoting the development of students' physical and mental health:

(1) Maintain healthy living habits. It required a reasonable arrangement of study time $(<3$ hours per day for lower graders and $<4$ hours for upper graders for elementary students; $<6$ hours for middle school students and $<7$ hours for high school students); sufficient sleep time (elementary school students $>10$ hours, and middle school students should be $>9$ hours); avoid staying up late and develop good habits to work on time; increase the interval between study and rest, take appropriate physical exercise to ensure physical and mental health; and learn to master the basic skills to prevent infectious diseases.

(2) Carry out physical exercise at home. Instruct parents to exercise with students. Its content was mainly based on basic skills (strength, flexibility, etc.), basic activities (such as jumping, supporting, balancing, etc.), and basic movements of some items (aerobics, hula hoop, jumping rope, etc.). Arrange 2 to 3 time a day with 20-30 minutes each.

(3) Insist on prevention and control of myopia, and control the length of time of using eyes. In elementary school, each class does not exceed 20 minutes, and the total length of online lessons per day does not exceed 80 minutes. Each 
middle school and high school class should less than 30 minutes each, and the total length of online lessons per day should not exceed 3 hours and 4 hours, respectively. The break time is not less than 15 minutes (looking for 10 minutes in the distance, rest with eyes closed, or do vision exercises for 5 minutes).

(4) Enrich cultural life at home. When choosing educational resources, the school should pay attention to recommending the content of art appreciation, film appreciation, calligraphy writing, sports and fitness to students. Guide them to take the theme of "fighting against pandemic", and carry out thematic activities such as film and television production, learning to sing songs, home sports, housework, and research projects (Education Department of Jiangsu, 2020).

\section{The Practical Significance of "School's Out, But Class's On"}

"School's Out, But Class's On" is the world's largest online school education practice. The postponement of the 2020 spring semester due to the COVID-19 pandemic has enabled 270 million students and nearly 20,000 full-time teachers across China to conduct online education and teaching activities. This is the pioneering work of online education in China and even around the world (Zhou, et al., 2020). Meanwhile, in the process of "School's Out, But Class's On", each school formulated specific work plans, schedules for curriculum, and clarified the distance teaching and assessment process. This allowed elementary and middle school students across the country to study at home according to the study schedule every day, and the school evaluated the students according to the planed teaching stage. This educational practice solved the problem of the actual education and teaching of Chinese schools that were postponed for the purpose of preventing and controlling the pandemic, and ensured that all students' learning was not affected by the pandemic, and its implementation effect had been recognized by the majority of students. A survey conducted by the China Education Policy Research Institute of Beijing Normal University showed that the satisfaction of home and elementary school students was generally high, and the vast majority of students acknowledged online learning methods and the learning effects (Jing \& Zhang, 2020).

"School's Out, But Class's On" education practice has tested the achievements of China's education construction of informatization. Since the 1980s, China has been continuing to promote the construction of education informatization with "three links and two platforms" as its core, and completed the project of "full coverage of digital education resources at teaching sites", which has enabled China to include teaching sites in remote rural areas with modern teaching equipment and nationally prescribed curriculum resources. Up to $2019,98.4 \%$ of China's elementary and middle schools (including teaching sites) have achieved network access. The national education resource public service system has been connected to 150 online platforms. In addition, there are Tencent classrooms, NetEase public courses, Chinese university MOOC, 
Homework Help, Learn+Think Online School, Ape tutoring, VIPKID and other educational platforms. Based on the construction of online platforms, China has also vigorously promoted the construction of high-quality digital education resources, including online courses, media material resources, and digital learning resource centers (Zhou, et al., 2020). These national-level online course resources provided strong educational technology and resource support for "School's Out, But Class's On" during the pandemic, thereby making it possible for schools across the country to develop online education and teaching.

"School's Out, But Class's On" educational practice is of great significance to the use of information technology to promote education and teaching reform. Online learning breaks the limitation of time and space and the limitation of the source flow of offline teaching, and makes a full use of the advantages of modern education technology. In online teaching, teachers use cutting-edge Internet technology to restore real teaching situations, and use massive electronic teaching resources to enrich teaching content, thereby achieving a rich, practical, and interesting live teaching. Students use the Internet to make learning choices more diverse and personalized, to make learning content and activities more free, and to make information technology and teaching more closely. Online teaching is considered to be an essential part of the future teaching mode, but since its rise in 2013, online learning has not become one of the popular teaching forms. The successful practice of "School's Out, But Class's On" provided valuable experience for the further implementation of online education, enriched people's understanding of online education, and increased the stickiness between technology and education. It is foreseeable that after the resumption of the normal school, the use of the Internet for autonomous learning and after-school supplementary learning will become a crucial way for students. Online teaching through the Internet will also become a critical style of teacher instructing. Using the network for teaching administration will also become an important form of school management (Zhou, et al., 2020).

"School's Out, But Class's On" is an educational response to the COVID-19 pandemic, but this should not be taken as a passive move under the crisis. On the contrary, we should combine the long-term task of reforming learning and teaching models in times of crisis to make it a good opportunity for school education reform. Schools should take advantage of this rare practical opportunity to re-examine the mission of school education in the spirit of reform, further consider the high-quality construction of educational resources, and the reconstruction of educational models and forms, and explore new types of education and teaching models. 


\section{References}

Dai, D., Lin, G. (2020) Online home study plan for postponed 2020 spring semester during the COVID-19 epidemic: A case study of Tangquan middle school in Nanjing, Jiangsu province, China. Best Evid Chin Edu, 4(2):543-547.

Education Department of Jiangsu. (2020) "Guiding opinions on further strengthening youth students' home study and life to promote the comprehensive development of physical and mental health during pandemic prevention and control", 2020-0302, http://jyt.jiangsu.gov.cn.

Gu, M. (1988) Dictionary of Education, Shanghai: Shanghai Education Press.

Henan Provincial Department of Education. (2020) Henan: Digital textbook service platform for primary and secondary schools is free and open, China Education Network, 2020-02-02.

Jing, A., Zhang, Z. (2020) School's Out, But Class's On: How effective is home study. Guangming Daily, Beijing, 2020-03-20.

Ministry of Education of the People's Republic of China. (2020) "Notice on Several Issues concerning Targeted Teacher Work during the Pandemic Prevention and Control", 2020-02-10, http://www.moe.gov.cn.

Ministry of Education of the People's Republic of China. (2020) "Notice on 'School's Out, But Class's On' Work Arrangements during the Postponed Period", 2020-02-12, http: //www.moe.gov.cn.

Ministry of Education of the People's Republic of China. (2020) "Notice on Coordinating the Prevention and Control of COVID-19 Pandemic in Education System and Education Reform and Development", 2020-02-28, http // www.moe.gov.cn.

Ministry of Education of the People's Republic of China. (2020) "Notice on Supporting Education and Teaching Work with Informationization during the Pandemic Prevention and Control Period", 2020-0206, http://www.moe. gov.cn.

Robert F. Service. (2020) 'The disruption is enormous.' Coronavirus epidemic snarls science worldwide.

Https://www.sciencemag.org/news/2020/ 02/disruption-enormous-coronavirusepidemic-snarls- science-worldwide, 0217 / 2020-03-20.

Shandong Provincial Institute of Education Sciences. (2020) "Opinions of Shandong Academy of Educational Sciences on strengthening the online teaching guidance of general primary and secondary schools", 2020-02-25, http://www.sdjky.net.

The Education Department of Guangdong Province. (2020) "Notice of the Guangdong Provincial Department of Education's Leading Group for the Prevention and Control of Pneumonia Pneumonia of New Coronavirus on strengthening the management of education and teaching in primary and secondary schools during the prevention and control of pandemic", 2020-02-07, http://edu.gd. gov.cn.

The Education Department of Shandong Province. (2020) "Four Grabs and Four Guarantees" in Weihai resolutely win the postponed "School epidemic prevention war", 2020-02-10, http // edu.shandong.gov.cn.

The Education Department of Zhejiang Province. (2020) "Ten suggestions for online teaching of junior high school by the Teaching and Research Office of Zhejiang Provincial Department of Education", 2020-02-21, http://jky.zj.gov.cn.

Xia, J.P. (2020) Teaching for student learning: Exploration of teaching strategies based on protocol-guided learning. Sci Insigt Edu Front, 5(1):451-467.

Xuzhou University Road Experimental School. (2020) WeChat public account: Xuzhou University Road Experimental School, 2020-01-30.

Zhejiang Provincial Teaching and Research Office. (2020) "How did online teaching develop during the pandemic?" How can it be improved? "Look at the data", "Digital Teaching in Primary and Middle Schools", Beijing, No. 3, 2020. 
Zhou, L., Li, C. (2020) Can student selfdirected learning improve their academic performance? Experimental evidence from the instruction of protocol-guided learning in China's elementary and middle schools. Sci Insigt Edu Front, 5(1):469-480.

Zhou, L., Li, F., Wu, S., \& Zhou M. (2020) "School's Out, But Class's On", The larg- est online education in the world today: Taking China's practical exploration during the COVID-19 epidemic prevention and control as an example. Best Evid Chin Edu, 4(2):501-519.

Zibo Municipal People's Government. (2020) "Zibo city takes many measures to do a good job in delayed school starts", 202002-06, http://edu.shandong.gov.cn.

Received: 21 March 2020

Revised: 27 March 2020

Accepted: 30 March 2020 